\title{
TREN PERIKAHAN DI BULAN PANTANGAN DI SIDOARJO
}

Kemal Riza, Eka Rahmawati, Faby Toriqir Rama, dan Muhammad Alwi Al-Maliki

Fakultas Syariah dan Hukum UIN Sunan Ampel Surabaya. E-mail: kemalespe@yahoo.com

\begin{abstract}
Javanese people believe that there are several months that are not well chosen as the wedding month, because there are calamities or disasters that will occur in the household, namely: Suro (Muharam), Mulud (Rabiul Awal), Poso (Ramadan), and Selo (Zulkaidab). This article further examines the attitude of urban communities who have received much internalization of understanding, cultural influences, and environmental conditions that are generally industrialists against the adat ban. There are three Religious Affairs Offices (KUA) in the Sidoarjo area that are used as research objects, namely (Waru, Sedati, and Buduran). ) The reason for choosing these three locations is the typography of the area that is mostly inhabited by traditionalist Muslim communities. But in the last decade, this region has changed, from an agricultural area that relies on agriculture and fish farming, to become an industrial area with the establishment of various types of factories and other types of businesses. Based on qualitative and quantitative data, there has been a trend of behavior change in the Sidoarjo community which in the period 1984-1985 the percentage of marriages on the month was avoided a little, it was seen that there was an additional percentage according to the data taken in the last 10 years. The people of Sidoarjo are now starting to move to not be fixated on the rules of the month election. In the past, the number of couples married at four months was avoided only slightly. And now, there is a change in tendency even though the percentage is not too significant.
\end{abstract}

Keywords: wedding trends and taboo's months

Abstrak: Orang Jawa meyakini adanya beberapa bulan yang tidak baik dipilih sebagai bulan pernikahan, karena ada bala' atau bencana yang akan terjadi di dalam rumah tangga, yaitu: Suro (Muharam), Mulud (Rabiul Awal), Poso (Ramadan), dan Selo (Zulkaidah). Artikel ini mengkaji lebih jauh sikap masyarakat perkotaan yang sudah banyak menerima internalisasi paham, pengaruh budaya, dan kondisi lingkungan yang umumnya industrialis terhadap larangan adat tersebut. Terdapat tiga Kantor Urusan Agama (KUA) di wilayah Sidoarjo yang digunakan sebagai objek penelitian, yakni (Waru, Sedati, dan Buduran). Alasan dipilihnya tiga lokasi ini adalah tipografi kawasan yang mayoritas dihuni oleh komunitas muslim tradisionalis. Tetapi dalam dekade terakhir, kawasan ini berubah, dari kawasan agraris yang mengandalkan pertanian

AL-HUKAMA

The Indonesian Journal of Islamic Family Law

Volume 08, Nomor 01, Juni 2018; ISSN:2089-7480 
dan budidaya ikan, menjadi kawasan industri dengan berdirinya berbagai jenis pabrik dan jenis usaha lainnya. Berdasarkan data kualitatif dan kuantitatif, telah terjadi tren perubahan perilaku masyarakat Sidoarjo yang pada periode 1984-1985 persentase perkawinan di bulan yang dihindari sedikit, terlihat ada penambahan persentase menurut data yang di ambil pada kurun waktu 10 tahun terakhir. Masyarakat Sidoarjo saat ini mulai tergerak untuk tidak terpaku kepada aturan pemilihan bulan. Dahulu, jumlah pasangan yang menikah di empat bulan yang dihindari hanya sedikit. Dan saat ini, terdapat perubahan tendensi walau persentasenya tidak terlalu signifikan.

Kata Kunci: tren pernikahan dan bulan pantangan

\section{Pendahuluan}

Dalam Islam, pernikahan merupakan suatu ikatan yang kokoh (mithaqan ghalizan). Aspek-aspek pernikahan pun diatur relatif detail. Bahkan dalam al-Qur'an, ayat-ayat yang membahas tentang pernikahan jauh lebih detail dibanding ayat-ayat yang mengatur tentang salat. Islam mengatur aspek-aspek pernikahan: pihak-pihak yang boleh dinikahi, perceraian dengan berbagai bentuk, bahkan hingga kewarisan. Pembahasan tentang pernikahan menempati satu bab besar dalam hukum Islam.

Akan tetapi, pembahasan tentang pernikahan yang mendetail dalam Islam tersebut tidak sampai meliputi bulan, hari, dan jam dilangsungkannya pernikahan. Islam hanya mengajarkan bahwa bulan-bulan dalam satu tahun jumlahnya dua belas. Dan di antara bulan-bulan tersebut, Tuhan menetapkan ada empat bulan haram. Sebagaimana secara eksplisit dipaparkan dalam ayat berikut:

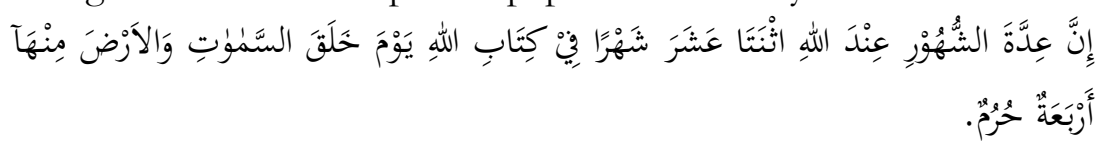

Sesunggubnya bilangan bulan pada sisi Allab adalah dua belas bulan, dalam ketetapan Allah di waktu Dia menciptakan langit dan bumi, di antaranya ada empat bulan haram. 1

Selain yang tersebut dalam ayat di atas, Islam tidak mengenal adanya bulan-bulan khusus yang dianggap perlu untuk dihindari ketika akan melangsungkan pernikahan. Sebaliknya, Nabi Muhammad bahkan melangsungkan perkawinan di bulan Syawal

1 Q.S. al-Taubah: 36 
sebagai bentuk penolakan terhadap anggapan masyarakat Arab kala itu bahwa bulan tersebut adalah bulan petaka, sial, buruk dsb. Hal ini dinarasikan langsung oleh Siti 'Aishah dalam sebuah Hadis:

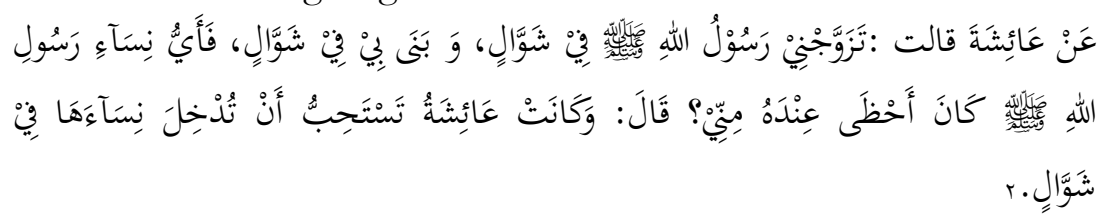

Dari 'Aishah berkata: "Rasulullah Saw menikabiku di bulan Syawal dan membangun rumah tangga bersamaku pada bulan Syawal. Maka manakah di antara istri-istri Rasululllah Saw yang lebib beruntung dibandingkan aku?" (Perawi) berkata babwa 'Aishah sering menikabkan para wanita di bulan Syawal.

Ibn Kathir menjelaskan, "Rasulullah Saw menikahi "Aishah di bulan Syawal untuk membantah keyakinan yang salah dari sebagian masyarakat, yaitu tidak suka menikah di antara dua 'id (bulan Syawal termasuk di antara Idul Fitri dan Idul Adha), mereka khawatir akan terjadi perceraian. Keyakinan ini sepenuhnya tidaklah benar."3

Imam Nawawi juga menjelaskan, "Di dalam hadis ini terdapat anjuran untuk menikahkan, menikah, dan membangun rumah tangga pada bulan Syawal. Para ulama kami (ulama Shafi'iyyah) telah menegaskan anjuran tersebut dan berdalil dengan hadis berikut: 'Dan 'Aishah ketika menceritakan hal ini bermaksud membantah apa yang diyakini masyarakat jahiliah dan anggapan takhayul sebagian orang awam pada masa kini yang menyatakan kemakruban menikah, menikabkan, dan membangun rumah tangga di bulan Syawal. Dan ini adalah batil, tidak ada dasarnya. Ini termasuke peninggalan jabiliah yang menganggap sial sesuatu.'."4

Selain hadis di atas, dari pernikahan-pernikahan yang dilakukan oleh Rasulullah Saw dapat disimpulkan, bahwa beliau

2 Abi al-Hasan Muslim ibn al-Hajjaj ibn Muslim al-Qushayri al-Naysaburi, Sabih Muslim, (Riyad: Dar al-Hadarah li al-Nashar wa al-Tawzi', 2015), 437.

3 Ibn Kathir, al-Bidayah wa al-Nihayah, Juz 3, (Kuwait: al-Muassasah Zad, 2001), 253.

4 Yahya ibn Sharaf al-Nawawi, Sharb Sahih Muslim, Juz 9, (Cairo: Dar al-Hadith, 2002), 209. 
tidak memilih waktu tertentu untuk menikah. Dalam sebuah penjelasan disebutkan, bahwa beliau menikah dengan Siti Khadijah di bulan Rabiul Awal, dengan Saudah bint Zam'ah pada bulan Syawal, dengan 'Aishah bint Abu Bakr pada bulan Syawal, dengan Hafsah bint 'Umar pada bulan Syakban, dengan Um Salamah Hindun bint Umayyah pada bulan Syawal, dengan Zaynab bint Jahshi pada bulan Zulkaidah, dengan Juwayriyah bint Harith pada bulan Syakban, dengan Um Habibah Ramlah bint Abi Sufyan pada bulan Muharam, dengan Safiyyah pada bulan Muharram dan dengan Maynunah pada bulan Zulkaidah.5

Di Indonesia-khususnya masyarakat Jawa-memiliki pandangan yang berbeda mengenai hal ini. Suku dan masyarakat Jawa memiliki serangkaian aturan dan ritual yang relatif kompleks, mengatur berbagai aspek yang terkait dengan pernikahan. Salah satu aspek yang diatur di dalam pernikahan masyarakat Jawa adalah adanya larangan untuk menikah di beberapa bulan tertentu dalam penanggalan Jawa. Secara umum, ada empat bulan yang harus dihindari untuk menikah: Suro (Muharam), Mulud (Rabiul Awal), Poso (Ramadan), dan Selo (Zulkaidah). Orang Jawa menganggap beberapa bulan itu tidak baik dipilih sebagai bulan pernikahan. Sebab ada bala' atau bencana yang akan terjadi di dalam rumah tangga seseorang manakala tetap bersikukuh untuk diterabas.

Penelitian ini, hendak menelisik lebih dalam terkait perilaku masyarakat perkotaan yang sudah banyak menerima internalisasi paham, pengaruh budaya, dan kondisi lingkungan yang umumnya industrialis. Terdapat tiga Kantor Urusan Agama (KUA) di wilayah Sidoarjo yang digunakan sebagai objek penelitian, yakni (Waru, Sedati, dan Buduran).

Alasan dipilihnya tiga lokasi ini adalah tipografi kawasan yang mayoritas dihuni oleh komunitas muslim tradisionalis. Tetapi dalam dekade terakhir, kawasan ini berubah dari yang awalnya kawasan agraris yang mengandalkan pertanian dan budidaya ikan, menjadi kawasan industri dengan berdirinya berbagai jenis pabrik

5 Islampos: Media Islam Generasi Baru, Pada Bulan-bulan Inilah Rasulullah Menikah, https://www/islampos.com/pada-bulan-bulan-inilah-rasulullahmenikah-126140/ 
dan jenis usaha lainnya. Kondisi inilah yang memungkinkan adanya trend/kecenderungan pergeseran perilaku dari yang awalnya skripturalis dan tradisionalis, menjadi modernis dan metropolis. Maka dari itu, penulis hendak menyibak lebih detail tentang fenomena tersebut berdasarkan alasan-alasan untuk tetap berpegang ataukah tidak terikatnya lagi dengan adat demikian. Data statistik juga disajikan untuk menambah keabsahan penelitian tidak hanya dari segi kualitatif, tetapi juga secara kuantitatifnya.

\section{Primbon Kejawen Terkait Pernikahan}

Masyarakat Jawa umumnya, masih memegang teguh warisan ilmu leluhur berupa "ilmu kejawen" yang mengaitkan penanggalan Jawa dengan berbagai peristiwa besar seperti pernikahan, kematian, kelahiran, hingga mengatur hal-hal yang spesifik seperti perhitungan tentang waktu dan tempat yang sesuai ketika akan membangun rumah, bahkan membuat sumur. Tujuannya adalah untuk mengetahui nasib baik atau buruk yang akan diterima.

Tata cara perhitungan tersebut dikodifikasikan dalam bentuk buku yang dinamakan Kitab Primbon yang terdiri dari delapan jilid. Namun, dalam penelitian ini, kitab yang digunakan adalah Kitab Primbon Betaljemur Adammakna yang merupakan jilid pertama. Di dalam seri pertama ini memuat berbagai pengetahuan tentang waktu yang patut untuk melaksanakan nikah, pemilihan jodoh berdasarkan weton, hingga prosesi upacara adat pernikahan.

Dalam tradisi penanggalan Jawa, nama-nama hari selalu disandingkan dengan pasaran yang terdiri dari: Kliwon, Legi, Pabing, Pon dan Wage. Kelima pasaran tadi berputar secara siklikal mengikuti tanggalan. Contohnya, Senin Wage, Selasa Kliwon, Jumat Legi dll. Masing-masing hari, pasaran, dan bulan memiliki neptu-nya (nilainya) sendiri.

Tabel 1. Neptu Hari dan Pasaran6

\begin{tabular}{|c|c|c|c|}
\hline Hari & Neptu & Pasaran & Neptu \\
\hline Minggu & 5 & Kliwon & 8 \\
\hline Senin & 4 & Legi & 5 \\
\hline
\end{tabular}

6 Harya Cakraningrat, Kitab Primbon: Betaljemur Adammakna, (Yogyakarta: Soemodidjojo Mahadewa, 2017), 7. 
Kemal Riza dkk.: Tren Pernikahan di Bulan Pantangan...

\begin{tabular}{|c|c|c|c|}
\hline Selasa & 3 & Pahing & 9 \\
\hline Rabu & 7 & Pon & 7 \\
\hline Kamis & 8 & Wage & 4 \\
\hline Jumat & 6 & & \\
\hline Sabtu & 9 & & \\
\hline
\end{tabular}

Tabel 2. Neptu Bulan7

\begin{tabular}{|c|c|c|c|}
\hline Bulan & Neptu & Bulan & Neptu \\
\hline Muharram & 7 & Rajab & 2 \\
\hline Safar & 2 & Syakban & 4 \\
\hline Rabiul Awal & 3 & Ramadan & 5 \\
\hline Rabiul Akhir & 5 & Syawal & 7 \\
\hline $\begin{array}{c}\text { Jumadil } \\
\text { Awal }\end{array}$ & 6 & Zulkaidah & 1 \\
\hline $\begin{array}{c}\text { Jumadil } \\
\text { Akhir }\end{array}$ & 1 & Zulhijah & 3 \\
\hline
\end{tabular}

1. Perhitungan Suami Istri (Petung Salaki Rabi)

Persoalan pemilihan jodoh atau seputar takdir yang mungkin akan diterima dari pasangan suami istri di dalam Kitab Primbon Betaljemur Adammakna memiliki berbagai macam versi perhitungan. Ada yang mendasarkan perhitungannya pada hari lahir dan pasarannya, ada pula yang mendasarkan pada aksara nama yang dimiliki masing-masing pasangan. Jadi, sepasang calon suami-istri sebelumnya dapat melihat perkiraan nasib mereka ke depannya.

a. Berdasarkan Weton

Weton masing-masing pasangan pengantin dijumlahkan (neptu hari + neptu pasarannya) kemudian dibagi sembilan. Selanjutnya dilihat berapa sisanya. Itulah yang dijadikan patokan. Contohnya, pengantin pria lahir pada Jumat Kliwon maka perhitungannya $6+8=14$ dibagi 9 sisa 5 . Sedangkan pengantin perempuan lahir pada Jumat Pahing $6+9=15$

7 Ibid., 
dibagi 9 sisanya 6. Jadi, pasangan yang terdiri dari 5 dan 6 menurut primbon rezekinya mapan. 8

Weton pengantin dijumlahkan semuanya dan dibagi empat. Kemudian dilihat berapa sisa yang ada. Misalkan weton pengantin pria adalah Jumat Pon maka neptu-nya $6+7$ $=13$. Dan pengantin wanita lahir pada Kamis Pahing maka neptu-nya $8+9=17$. Kemudian $17+13=30$ dibagi 4 sisa 2 . Maka dia akan memiliki banyak keturunan. Ketentuannya, kalau sisa 1 maka susah mendapat keturunan. Kalau sisa 2 banyak anak, kalau sisa 3 banyak rezeki, dan kalau sisa 4 maka salah satu ada yang mati. 9

Ada juga versi yang lebih sederhana, yakni patokannya didasarkan pada hari kelahirannya saja, tanpa dihitung neptunya. Misalkan, jika pasangan pengantin sama-sama lahir di hari Minggu, maka akan sering dijangkiti penyakit. Jika pasangannya lahir di bulan Senin dan Rabu, maka ia akan memiliki seorang putri. Dan jika pasangannya lahir di hari Kamis dan Sabtu maka kelak akan bercerai.10

b. Berdasarkan Nama

Perhitungan jenis ini menggunakan nama depan dan/atau nama belakang yang ditulis ke dalam aksara Jawa. Jenis ini juga terdapat banyak versi, sama halnya dengan jenis perhitungan yang menggunakan weton. Dalam hal ini, ada yang menggunakan aksara yang diambil dari nama depan dan nama belakang. Masing-masing aksara punya neptu-nya sendiri-sendiri. Ada pula yang hanya diambil dari aksara depan saja.

2. Waktu Pelaksanaan Pernikahan

Pelaksanaan atau tanggal pesta pernikahan (walimah al-urs) juga perlu dihitung dengan tujuan mengetahui waktu yang baik dan yang buruk. Perhitungan ini juga terdapat banyak versi, tetapi diperbolehkan memakai salah satu di antaranya. Berikut penjelasan detailnya.

8 Ibid., 12.

9 Ibid., 13.

10 Ibid. 


\section{a. Anggarakasib}

Dilarang untuk melaksanakan pernikahan pada setiap bulan Hijriah/Jawa yang ada hari Selasa Kliwonnya atau disebut "Anggarakasih". Larangan ini tidak hanya berlaku untuk melakukan akad nikah saja, tetapi juga mencakup hal lainnya seperti bepergian ke luar rumah.11

b. Hari Buruk (Dino Ala)

Dilarang melangsungkan pernikahan pada hari-hari buruk yang terangkum dalam tabel berikut:

Tabel 3. Dina Ala12

\begin{tabular}{|l|l|}
\hline Bulan & Hari Buruk \\
\hline $\begin{array}{l}\text { Jumadil Akhir, Rajab, } \\
\text { Syakban }\end{array}$ & Jumat \\
\hline $\begin{array}{l}\text { Ramadan, Syawal, } \\
\text { Zulkaidah }\end{array}$ & Sabtu, Minggu \\
\hline Zulhijah, Muharam, Safar & Senin, Selasa \\
\hline $\begin{array}{l}\text { Rabiul Awal, Rabiul Akhir, } \\
\text { Jumadil Awal }\end{array}$ & Rabu, Kamis \\
\hline
\end{tabular}

c. Hari yang Menakutkan (Dina Sangaring Sasi)

Tidak jauh berbeda dengan dina ala, ketika menemui dina sangar, masyarakat juga dilarang untuk melangsungkan pernikahan yang terangkum sebagai berikut:

Tabel 4. Dina Sangaring Sasi13

\begin{tabular}{|l|l|}
\hline Bulan & Hari Sangar \\
\hline Ramadan, Syawal, Zulkaidah & Jumat \\
\hline Zulhijah, Muharam, Safar & Sabtu, Minggu \\
\hline $\begin{array}{l}\text { Rabiul Awal, Rabiul Akhir, Jumadil } \\
\text { Awal }\end{array}$ & Senin, Selasa \\
\hline Jumadil Akhir, Rajab, Syakban & Rabu, Kamis \\
\hline
\end{tabular}

d. Hari Para Nabi Menerima Cobaan (Na'asing Para Nabi)

11 Ibid., 11.

12 Ibid., 18.

13 Ibid., 19. 
Kemal Riza dkk.: Tren Pernikahan di Bulan Pantangan...

Dilarang melaksanakan pernikahan sebab pada tanggaltanggal yang tersebut di bawah ini, para Nabi terdahulu menerima cobaan/ujian dari Allah Swt.

Tabel 5. Na'asing Para Nabi14

\begin{tabular}{|c|c|c|}
\hline Bulan & Tanggal & Sebab \\
\hline Muharam & 13 & $\begin{array}{l}\text { Nabi Ibrahim dibakar Raja } \\
\text { Namrud }\end{array}$ \\
\hline Rabiul Awal & 3 & $\begin{array}{lll}\text { Nabi Adam diturunkan di } \\
\text { dunia }\end{array}$ \\
\hline $\begin{array}{l}\text { Rabiul } \\
\text { Akhir }\end{array}$ & 16 & $\begin{array}{llll}\text { Nabi } & \text { Yusuf dijatuhkan di } \\
\text { sumur }\end{array}$ \\
\hline $\begin{array}{l}\text { Jumadil } \\
\text { Awal }\end{array}$ & 5 & Nabi Nuh dilanda kebanjiran \\
\hline Ramadan & 21 & $\begin{array}{l}\text { Nabi Musa berperang dengan } \\
\text { Raja Firaun }\end{array}$ \\
\hline Zulkaidah & 24 & Nabi Yunus dimakan oleh ikan \\
\hline Zulhijah & 25 & $\begin{array}{l}\text { Nabi Muhammad masuk ke } \\
\text { gua }\end{array}$ \\
\hline
\end{tabular}

e. Bangas Padewan

Tidak diperbolehkan untuk melangsungkan pernikahan, jika dilanggar maka sangat besar peluangnya di kemudian hari akan menemui kesusahan. Setiap bulan mempunyai tanggal bangas padewan.

Tabel 6. Bangas Padewan15

\begin{tabular}{|l|l|l|l|l|l|l|}
\hline Bulan & \multicolumn{2}{|l|}{ Tanggal } & Bulan & \multicolumn{2}{|l|}{ Tanggal } & Bulan \\
\hline Muharam & 11 & - & Rajab & 13 & 27 & Muharam \\
\hline Safar & 20 & - & Syakban & 4 & 28 & Safar \\
\hline $\begin{array}{l}\text { Rabiul } \\
\text { Awal }\end{array}$ & 1 & 15 & Ramadan & 7 & 20 & $\begin{array}{l}\text { Rabiul } \\
\text { Awal }\end{array}$ \\
\hline $\begin{array}{l}\text { Rabiul } \\
\text { Akhir }\end{array}$ & 10 & 20 & Syawal & 10 & - & $\begin{array}{l}\text { Rabiul } \\
\text { Akhir }\end{array}$ \\
\hline
\end{tabular}

14 Ibid.

15 Ibid., 20. 
Kemal Riza dkk.: Tren Pernikahan di Bulan Pantangan...

\begin{tabular}{|l|l|l|l|l|l|l|}
\hline $\begin{array}{l}\text { Jumadil } \\
\text { Awal }\end{array}$ & 10 & 11 & Zulkaidah & 2 & 22 & $\begin{array}{l}\text { Jumadil } \\
\text { Awal }\end{array}$ \\
\hline
\end{tabular}

f. Bulan Baik dan Buruk untuk Melangsungkan Pernikahan

\begin{tabular}{|l|l|l|}
\hline No. & Bulan & Akibat \\
\hline 1. & Muharam & $\begin{array}{l}\text { Sering bertengkar, menemui kerusakan } \\
\text { (jangan dilanggar) }\end{array}$ \\
\hline 2. & Safar & $\begin{array}{l}\text { Kekurangan rezeki, kaya utang (boleh } \\
\text { dilanggar) }\end{array}$ \\
\hline 3. & $\begin{array}{l}\text { Rabiul } \\
\text { Awal }\end{array}$ & $\begin{array}{l}\text { Salah satu pasangan akan meninggal } \\
\text { (jangan dilanggar) }\end{array}$ \\
\hline 4. & $\begin{array}{l}\text { Rabiul } \\
\text { Akhir }\end{array}$ & $\begin{array}{l}\text { Akan dicaci dan sering menemui ujaran } \\
\text { kebencian (boleh dilanggar }\end{array}$ \\
\hline 5. & $\begin{array}{l}\text { Jumadil } \\
\text { Awal }\end{array}$ & $\begin{array}{l}\text { Sering kehilangan barang, terkena } \\
\text { penipuan, dan banyak mendapat celaan } \\
\text { (boleh dilanggar) }\end{array}$ \\
\hline 6. & $\begin{array}{l}\text { Jumadil } \\
\text { Akhir }\end{array}$ & $\begin{array}{l}\text { Diberkati dengan kekayaan emas dan } \\
\text { perak }\end{array}$ \\
\hline 7. & Rajab & $\begin{array}{l}\text { Banyak dikaruniai keturunan dan } \\
\text { keselamatan }\end{array}$ \\
\hline 8. & Syakban & $\begin{array}{l}\text { Diberikan keselamatan atas segala } \\
\text { aspek kehidupannya }\end{array}$ \\
\hline 9. & Ramadan & $\begin{array}{l}\text { Bencana besar (jangan dilanggar) } \\
\text { Kekurangan rezeki dan kaya hutang } \\
\text { (boleh dilanggar) }\end{array}$ \\
\hline 10. & Syawal & $\begin{array}{l}\text { Dilanda sakit dan sering bercekcok } \\
\text { (jangan dilanggar) }\end{array}$ \\
\hline 11. & Zulkaidan kemakmuran \\
\hline 12. & Zulhijah & \begin{tabular}{l} 
Kaya dan mendapatkan kemakm \\
\hline
\end{tabular} \\
\hline
\end{tabular}

\section{Pandangan Masyarakat Sidoarjo Mengenai Bulan Pantangan Menikah}

Dalam penelitian ini, ada tiga lokasi yang dijadikan sumber data, yaitu wilayah Kecamatan Waru Kecamatan Sedati dan Kecamatan Buduran. Secara khusus, petugas pencatat nikah/penghulu di tiga 
kecamatan tersebut, beberapa modin dan masyarakat, diwawancarai untuk menghimpun data tentang hal ini.

1. Masyarakat Kecamatan Waru

a. Kepala KUA Waru

Terkait macam bulan pernikahan, Pihak KUA menyatakan tidak berwenang dalam memberikan informasi tentang macam-macam bulan pernikahan. Karena, tugas dan kewenangan KUA hanya sebatas melayani pendaftaran serta konsultasi bagi calon pengantin. Namun, pihak KUA tidak menyangkal, bahwa dalam adat masyarakat muslim Jawa, masih kental kepercayaan terhadap bulan-bulan hijriah hijriyah tertentu sebagai bulan-bulan pernikahan.

Masyarakat Muslim di wilayah ini mengenal macammacam bulan hijriah yang digabung dengan kepercayaan adat setempat sehingga menghasilkan tradisi seputar pernikahan yang kemudian diterapkan dalam penentuan tanggal akad pernikahan. Kepercayaan ini dibuktikan dengan jumlah pasangan pengantin menikah di setiap tahunnya dalam buku register akta Nikah di KUA Waru yang biasanya terjadi di bulan Rajab, Syawal, dan Zulhijah. Ketiga bulan tersebut diyakini masyarakat sebagai bulan yang baik untuk dilakukan akad nikah.

Pernikahan di luar bulan-bulan baik juga masih dilakukan oleh beberapa orang karena keadaan mendesak demi kemaslahatan kedua calon pengantin. Keadaan mendesak tersebut antara lain: calon pengantin perempuan hamil sebelum menikah, keperluan untuk pergi ke luar negeri, orang tua mempelai sakit keras atau wafat, dan sudah tidak dipercayainya keutamaan-keutamaan bulan-bulan tersebut. Data dari buku register akta nikah menunjukkan, bahwa pernikahan di luar bulan-bulan baik masih sedikit jumlahnya.

Masyarakat daerah Waru masih mempercayai tradisi hitungan Jawa, pernikahan di bulan baik, maupun pantangan menikah dibulan yang tidak dianjurkan. Mayoritas 
pemahaman seperti ini dianut oleh masyarakat yang memiliki latar belakang Nahdlatul Ulama (NU).16

b. Pandangan Penghulu KUA Waru

Menurut penuturan seorang penghulu di Kecamatan Waru, di kalangan Masyarakat Kecamatan Waru, beredar cerita yang beragam terkait pemilihan bulan menikah. Ada yang meyakini bulan baik dan buruk, ada pula yang tidak, walaupun jumlahnya sedikit. Biasanya, pasangan akan menikah di bulan Bakda Mulud (Rabiulakhir), Syawal, dan Besar (Zulhijah). Sedangkan bulan yang menjadi pantangan adalah bulan Suro (Muharam). Tidak ada alasan keagamaan dalam hal ini, semua hanya didasarkan pada keyakinan adat masyarakat setempat.

Penentu tanggal perkawinan, biasanya adalah orang tua atau kiai setempat. Pihak KUA mengaku tidak tahu alasan pasti memilih tanggal tertentu. Masyarakat yang menikah di luar bulan baik biasanya ada sebab yang mendesak seperti sudah hamil di luar nikah, atau suaminya akan berdinas di luar kota.

Perkawinan yang dilakukan di bulan-bulan yang biasa (tidak baik juga tidak buruk) juga banyak dilakukan masyarakat Waru. Dalam satu tahun KUA Kecamatan Waru dapat melayani 1400 pasangan. Kendatipun demikian, jumlahnya tidak sebanyak pasangan yang menikah di bulanbulan baik.

Terkait pemilihan bulan ini, masyarakat NU masih kental dengan perhitungan-perhitungan kejawen. sementara kebanyakan masyarakat Muhammadiyah tidak terlalu memperhatikan hal tersebut. Mereka lebih memilih hari yang pertimbangannya adalah hari libur (Sabtu dan Minggu) supaya keluarga dapat berkumpul dan tidak ada pertimbangan perhitungan karena adat. 17

c. Pandangan Modin/Pembantu Pejabat Pencatat Nikah Kecamatan Waru 
Menurut Misbahul Munir, seorang modin di salah satu kelurahan di Kecamatan Waru, bulan Zulhijah adalah bulan yang paling ramai pasangan menikah. Hal yang sama terjadi di semua KUA yang menjadi objek penelitian. Misbahul Munir menuturkan, bahwa bulan Besar (Zulhijah) adalah yang paling ramai, disusul Syawal di tempat kedua. Dia mengakui, bahwa tidak ada alasan keagamaan terkait pemilihan bulan-bulan tertentu. Semua berawal dari adat masyarakat setempat yang menganggap bulan-bulan tertentu dapat mendatangkan kebaikan. Kepercayaan masyarakat tidak hanya pada pemilihan bulan, tetapi sampai pada posisi duduk saat akad nikah dilaksanakan. Misalnya, jika pasangan yang akad menghadap ke utara, maka diyakini bakal iwuh rezekine. Jika menghadap ke selatan, diyakini cepat meninggal. Orang yang berpendapat demikian adalah masyarakat yang sangat fanatik dengan adat leluhur mereka.

Pemilihan hari untuk menikah juga diatur berdasarkan adat, disamping dipengaruhi nilai-nilai Islam. Hari Jumat misalnya, menjadi pilihan utama melaksanakan pernikahan karena ada sabda Rasulullah yang menyatakan, bahwa hari jum'at adalah sayyid al-ayyam (hari paling utama). Pernikahan pada hari Kamis setelah sholat ashar juga banyak dilakukan, karena menurut keyakinan masyarakat sudah masuk hari selanjutnya.

Sebagian masyarakat ada juga yang meyakini jam-jam tertentu yang baik untuk menikah. Misbahul Munir mengatakan, bahwa ia pernah menikahkan pasangan setelah jam 00.00 WIB. Alasan pasangan yang minta dinikahkan pada jam tersebut adalah karena jika tidak dilaksanakan pada jam tersebut, pernikahannya harus mundur selama satu tahun. Karena hitungannya sudah sampai di situ.

Menurut Misbahul Munir, pada masa lalu, yang berhak menentukan tanggal pernikahan adalah Ayah mempelai wanita atau dalam fikih disebut wali mujbir. Sekarang semuanya diserahkan kepada pasangan yang akan melangsungkan perkawinan. Pada masa lalu masih banyak praktik perjodohan. Orang tua punya otoritas penuh untuk 
mengatur kapan dan dengan siapa anaknya akan menikah. Selain itu, ada juga yang meminta fatwa kiai untuk menentukan tanggal pernikahan. Masyarakat yang sudah meyakini tanggal yang difatwakan kiai, enggan untuk memundurkan atau memajukan.

Munir menilai, bahwa mulai ada pergeseran nilai di tengah masyarakat. Pengaruh adat sudah berkurang, dibuktikan dengan banyaknya pasangan yang menikah di bulan-bulan yang seharusnya pantangan, seperti Muharram. Sedangkan motivasi utama seseorang menikah di luar bulan-bulan baik menurut Munir adalah agama, terlepas dari hitungan. Mereka yang yakin hanya kepada Allah, kapan pun bulannya, harinya, maupun jamnya, asal ada waktu luang untuk menikah, itulah waktu terbaik. Mereka yang melakukan praktik menikah di luar bulan-bulan baik ini tidak bisa dipastikan Munir berasal dari organisasi apa, apakah NU, Muhammadiyah, LDII, dan HTI. Ia menjawab bahwa penghulu atau modin hanya sebatas pelayan masyarakat.18

2. Masyarakat Kecamatan Sedati

a. Kepala KUA Sedati

Menurut pandangan Abdul Muntolib, kepala KUA Sedati, bisa dipastikan seluruh bulan dalam satu tahun (masehi) selalu terjadi pernikahan. Namun, calon pengantin menikah biasanya paling sering terjadi di bulan Rajab, Syawal, dan Zulhijah. Abdul Muntolib menyatakan bahwa bulan-bulan hijriyah ada yang digolongkan kepada bulan baik untuk menikah dan ada pula yang digolongkan kepada bulan pantangan untuk menikah. Tidak ada alasan yang bersifat keagamaan dalam hal ini, karena keyakinan seperti ini berdasarkan adat turun temurun, yaitu adat Jawa.

Pernikahan di luar bulan-bulan baik (bulan pantangan) biasanya terjadi pada bulan Muharram, Zulkaidah, dan Ramadan. Namun, hal itu jarang terjadi (sedikit). Berdasarkan data statistik, dari tahun ke tahun jumlah pernikahan tetap stabil atau relatif, yaitu pernikahan di bulan

18 Misbahul Munir, Wawancara, 03 Oktober 2017. 
menikah tetap ramai dan di luar bulan pernikahan tetap sepi. Menurut pandangan Abdul Muntolib, pernikahan dilakukan di luar bulan-bulan menikah karena dua alasan: pertama, tidak meyakini adanya bulan baik atau bulan pantangan menikah kedua, keadaan mendesak. Kondisi mendesak di sini seperti terjadi kehamilan sebelum akad nikah, atau pun alasan pergi ke luar negeri.

Abdul Muntolib lantas menyimpulkan, bahwa secara umum, pernikahan di luar bulan-bulan menikah banyak dilakukan oleh masyarakat NU, karena memang mayoritas masyarakat Sedati adalah warga NU. Namun, terkadang juga pernah dilakukan oleh warga Muhammadiyah serta kalangan abangan. 19

b. Penghulu KUA Sedati

Sebagaimana penjelasan lainnya, Ischaq Fanani, penghulu di KUA Kecamatan Sedati, juga menyatakan, bahwa pasangan biasanya memilih tanggal perkawinan Mulud, Bakda Mulud, Syawal, dan Besar. Bulan pantangan pasangan menikah adalah bulan Suro (Muharram), Selo (Zulkaidah), dan Ramadan. Sedangkan bulan Safar adalah netral, tidak ada pantangan maupun keutamaan. Untuk perkawinan di luar bulan-bulan favorit memang tidak seberapa banyak. Dari tahun ke tahun tetap saja sedikit, contohnya di bulan Muharram. Alasan menikah di luar bulan-bulan favorit biasanya karena hamil di luar nikah, atau salah satu pasangan hendak bertugas ke luar kota sehingga harus segera dinikahkan.20

c. Modin KUA Sedati

Pernyataan yang sama juga disampaikan oleh M. Sochibulloh, Modin wilayah Sedati. Ia menyatakan, bahwa dalam setahun, tiap bulannya pasti ada pernikahan, tetapi builan yang paling banyak jumlah pasangan menikahnya adalah bulan Syawal, Zulhijah, dan Rabiulakhir. Selama beliau menjadi penghulu, tiga bulan tersebut banyak menjadi

19 Abd. Muntholib, Wawancara, 29 September 2017.

20 Ischaq Fathani, Wawancara, 27 September 2017. 
pilihan pasangan menikah. Sedangkan bulan yang menjadi pantangan, meskipun beliau sendiri tidak meyakininya sebagai suatu hal yang harus dilakukan, antara lain bulan Muharam, Ramadan, dan Zulkaidah. Rata-rata orang yang menikah pada bulan yang dianggap pantangan ini tidak peduli terhadap konsekuensi yang diyakini masyarakat. Mereka yang biasanya menikah di bulan-bulan pantangan ini adalah pasangan yang hamil di luar nikah, pasangan janda dan duda, pasangan yang sudah menikah secara siri.

Sochibulloh mengakui, bahwa pemilihan bulan tersebut tidak ada dalilnya, karena dalam al-Qur'an hanya dijelaskan tentang konsep empat bulan haram (mulia), dan Rasul sendiri menikahi istri-istrinya juga tidak memperhitungkan bulan. Menurutnya, tradisi pemilihan tersebut berasal dari mitos orang Jawa yang masih diyakini sampai sekarang oleh sebagian masyarakat Muslim Jawa di Sidoarjo. Lebih lanjut dia menjelaskan, bahwa kepercayaan yang baik dari tren ini adalah dalam memilih hari. Rata-rata catin, dalam bulanbulan baik tadi memilih menikah pada hari Jumat, khususnya Jumat Legi. Mereka berpandangan, bahwa hari Jumat adalah hari yang paling baik. Pemilihan ini menurut beliau terkadang berasal dari kehendak catin pribadi, tetapi kebanyakan yang terjadi di Sedati adalah karena turut andilnya tokoh masyarakat: kiai atau tokoh lainnya yang dianggap paham agama Islam. Selanjutnya, dia menyampaikan, bahwa di era milenium ini, praktik tersebut masih ada dan dilakukan. Namun persentasenya pada sepuluh tahun terakhir cenderung menurun. Kenyataan ini menggambarkan, bahwa pola pikir dan keyakinan masyarakat terhadap tradisi ini mulai luntur dan beranjak tidak dipakai.21

3. Masyarakat Kecamatan Buduran

a. Kepala KUA Buduran

Muhammad Khusaeri, kepala KUA Buduran berpandangan, bahwa pada hakikatnya di semua bulan-bulan hijriah selalu terjadi pernikahan. Akan tetapi, ada istilah

21 M. Soochibullah, Wawancara, 10 Oktober 2017. 
bulan baik untuk menikah dan bulan pantangan untuk menikah. Kepercayaan seperti ini merupakan hukum adat turun-temurun yang dipercayai oleh mayoritas masyarakat muslim Jawa, khususnya di daerah Buduran. Bulan Rajab, Syawal, dan Zulhijah merupakan bulan yang paling banyak diminati masyarakat Buduran untuk melangsungkan akad nikah.

Keyakinan seperti ini merupakan keyakinan turun temurun. Namun, di era sekarang terdapat pergeseran keyakinan terhadap anjuran atau pantangan di bulan-bulan tertentu. Karena, bagi mereka sudah tidak lazim lagi untuk dilakukan, terutama bagi anak muda. Sehingga, pernikahan di luar bulan baik ataupun pernikahan di bulan-bulan umum tetap diterjang bagi kalangan tertentu masyarakat. Hal ini terjadi karena memang mereka sudah tidak mempercayai adanya pernikahan di bulan baik atau pantangan.

Selain hal itu, Khusaeri juga memandang, bahwa masyarakat tetap melakukan pernikahan pada bulan pantangan karena keadaan mendesak, seperti terjadi kehamilan di luar nikah, orang tua meninggal, atau bagi anggota TNI, ditugaskan di luar pulau atau luar negeri. Pernikahan di luar bulan-bulan yang umum itu dilakukan oleh masyarakat muslim pada umumnya, baik yang berlatar belakang NU ataupun Muhammadiyah, meskipun masyarakat Muhammadiyah tidak begitu mempercayai adat.

Hal ini terbukti dengan adanya pernikahan di luar bulan baik walaupun jumlahnya sedikit. Meskipun terjadi pergeseran keyakinan terhadap anjuran dan pantangan menikah di bulan-bulan tertentu, berdasarkan data di Buku Register Akta Nikah KUA Buduran, tiap tahunnya masih berjalan stabil. Dengan Persentase pernikahan di bulan menikah adalah $90 \%$ dan di bulan pantangan adalah 10\%.22

b. Penghulu KUA Buduran

Sejalan dengan penjelasan tersebut, Abdul Ghofur, seorang penghulu di KUA Buduran menyatakan, bahwa

22 Muhammad Khusaeri, Wawancara, 29 September 2017. 
dalam satu tahun, tiap bulannya pasti terdapat pernikahan. Namun yang paling sering dan banyak jumlahnya adalah bulan Syawal, Zulhijah, dan Rabiulakhir. Selama menjadi penghulu, tiga bulan tersebut yang sering dan banyak orang nikah.

Sedangkan bulan yang menjadi pantangan, meskipun beliau sendiri tidak meyakininya sebagai suatu hal yang harus dilakukan, antara lain bulan Muharam, Ramadan, dan Zulkaidah. Rata-rata orang yang menikah pada bulan yang dianggap pantangan ini tidak peduli terhadap konsekuensi yang mereka yakini. Mereka adalah pasangan yang hamil di luar nikah, pasangan janda dan duda, pasangan yang sudah nikah siri. Beliau mengakui, bahwa pantangan tersebut tidaklah ada dalilnya karena dalam Quran hanya dijelaskan tentang konsep 4 bulan haram (mulia), dan Rasul sendiri menikahi istri-istrinya juga tidak memperhitungkan bulan. Menurutnya, tradisi pemilihan tersebut berasal dari mitos orang Jawa yang masih dipakai sampai sekarang oleh sebagian masyarakat Muslim Jawa di Sidoarjo.

Lebih lanjut dia menjelaskan bahwa kepercayaan yang baik dari tren ini adalah dalam memilih hari, rata-rata catin dalam bulan-bulan baik tadi memilih menikah pada hari Jumat, khususnya Jumat Legi. Mereka berpandangan, bahwa hari Jumat adalah hari yang paling baik. Pemilihan ini menurut beliau terkadang berasal dari kehendak catin pribadi, namun kebanyakan yang terjadi di Buduran adalah turut andilnya tokoh masyarakat dalam hal ini kiai atau tokoh yang dianggap paham agama Islam.23

c. Modin KUA Buduran

Sejalan penuturan di atas, Chudlori, seorang modin di wilayah Buduran mengatakan, bahwa perkawinan memang paling banyak dilaksanakan pada bulan Besar, Mulud, dan Bakda Mulud. Saat itu petugas sangat sibuk, terutama modin, untuk menikahkan pasangan. Chudlori mengakui bahwa memang ada keyakinan tentang bulan baik dan bulan buruk

23 Abdul Ghofur, Wawancara, 06 Oktober 2017. 
yang berasal dari leluhur. Tetapi secara umum tidak ada dalil yang menjelaskan hal tersebut. Begitu pula dengan pemilihan hari. Biasanya masyarakat memilih hari Jumat, karena hari Jum'at adalah hari yang penting. Untuk jamnya maksimal jam 11 siang atau setidak-tidaknya sebelum khatib naik ke mimbar untuk menyampaikan khotbah Jumat. Pernikahan setelah salat Jumatan jarang terjadi. Sedangkan pemilihan tanggal, biasanya ditetapkan melalui musyawarah keluarga. Pasangan yang akan menikah sudah menentukan tanggal yang pasti. Penghulu tidak menanyakan lebih jauh terkait pemilihan tanggal tersebut.

Secara umum, tidak dapat disimpulkan jumlah perkawinan di bulan-bulan tertentu, apakah terjadi tren naik ataukah turun. Karena pelaksanaan akad nikah kebanyakan dilakukan di KUA tempat domisili istri. Jika di suatu kecamatan jumlah wanitanya banyak, maka akan banyak terjadi peristiwa pernikahan. Sebaliknya, jika dalam suatu kecamatan terdapat sedikit wanita, maka akan terjadi sedikit perkawinan. Khusus di Kecamatan Buduran, untuk tahun 2016 memang lebih banyak perempuannya. Di tahun 2017 ini sedikit sekali perempuan yang menikah, sehingga rata-rata mereka melakukan prosedur pindah nikah ke KUA yang membawahi wilayah calon istrinya. Jadi tidak dapat diasumsikan dari tahun ke tahun ada penambahan atau pengurangan.

Untuk perkawinan yang terjadi di luar bulan-bulan baik, memang tidak dapat diketahui alasannya secara pasti. Juga tidak bias ditentukan ormasnya, karena baik warga NU maupun Muhammadiyah, pernah melakukan perkawinan di luar bulan baik.24

4. Pasangan yang Menikah di Bulan yang Dihindari

Selain data yang diperoleh dari pihak KUA, beberapa pasangan pengantin yang menikah di bulan pantangan juga diwawancarai. Pasangan pertama yang diwawancarai, menikah di hari Jumat, 6 Oktober 2017 Pukul 14.00 WIB. Mempelai pria

24 Chudlori, Wawancara, 09 Oktober 2017. 
menuturkan, bahwa alasannya menikah di bulan Muharram bukan karena alasan agama, lebih-lebih alasan adat masyarakat setempat. Mereka meyakini bahwa bulan Muharram adalah bulan yang baik-bulan yang penuh kenikmatan. Pernyataan tersebut juga dituturkan oleh salah seorang pengiring yang ikut masuk ke Balai Nikah KUA Waru. Hari Jumat dipilih karena hari yang bagus. Mempelai pria dan wanita sendiri yang menentukan hari dan tanggalnya, meskipun ada musyawarah dari kedua belah pihak keluarga. Ketika ditanya perihal latar belakang pendidikannya, calon suami dahulu pernah mengenyam pendidikan di salah satu pesantren di Banyuwangi. Ia juga melanjutkan karier akademisnya sampai ke jenjang S1. Selain itu, ia mengaku bahwa tergabung dalam salah satu ormas Islam minoritas di Indonesia, yaitu LDII (Lembaga Dakwah Islam Indonesia). 25

Sepasang pengantin lainnya yang pernikahannya dilaksanakan di KUA Buduran dan beberapa pengiring, menyatakan, bahwa alasan mereka menikah pada bulan Muharram yang bertepatan dengan hari Senin, 9 Oktober 2017 Pukul 13.30 WIB, adalah karena mereka tidak meyakini adanya bulan pantangan. Mereka memandang, bahwa semua bulan adalah baik. Mereka tidak meyakini adat primbon Jawa. Tidak ada bulan pantangan. Yang terpenting dari pelaksanaan akad nikah bukan terletak pada pemilihan bulannya, tetapi kelurusan niatnya, yakni untuk beribadah kepada Allah Swt. Ketika ditanya lebih dalam, paman mempelai laki-laki menerangkan, bahwa ayah mempelai prialah yang menentukan tanggal perkawinan yang disetujui dalam musyawarah keluarga. Terkait latar belakang pendidikan, mempelai pria mengaku lulusan SMK dan sudah bekerja. Sementara istri mengenyam pendidikan sampai tingkat SLTP saja. Mereka juga mengaku tidak tergabung ke dalam ormas Islam apa pun.26

\section{Data Statistik Perkawinan di KUA Waru, Sedati, dan Buduran}

25 Amin Tohari, Wawancara, 06 Oktober 2017.

26 Fatkur Rochman, Wawancara, 09 Oktober 2017. 
Penuturan beberapa pihak di atas sejalan dengan data statistik yang dikumpulkan dari 3 (tiga) KUA di wilayah Sidoarjo yang menjadi lokasi penelitian ini, yaitu Waru, Sedati dan Buduran. Ada dua jenis data statistik yang digunakan dalam penelitian ini, yaitu data tren pemilihan bulan menikah dalam kurun 10 tahun terakhir untuk menunjukkan ada atau tidaknya perubahan tren dalam kurun waktu tersebut dan data jumlah pernikahan di tahun 1984-1985 untuk menunjukkan situasi pemilihan menikah di era tahun 1980an dengan asumsi pada era tersebut pemilihan bulan menikah lebih memenuhi ketentuan adat setempat dibanding dengan tahun-tahun terakhir ini.

Di kecamatan Sedati, terdapat 5.852 perkawinan dalam kurun waktu 10 tahun terakhir. Rata-rata terdapat 582.2 perkawinan tiap tahunnya. Sebaran bulan hijriah perkawinan tersebut sebagaimana dalam gambar di bawah ini:

Gambar 1: Jumlah Perkawinan di Kecamatan Sedati 2007-2017

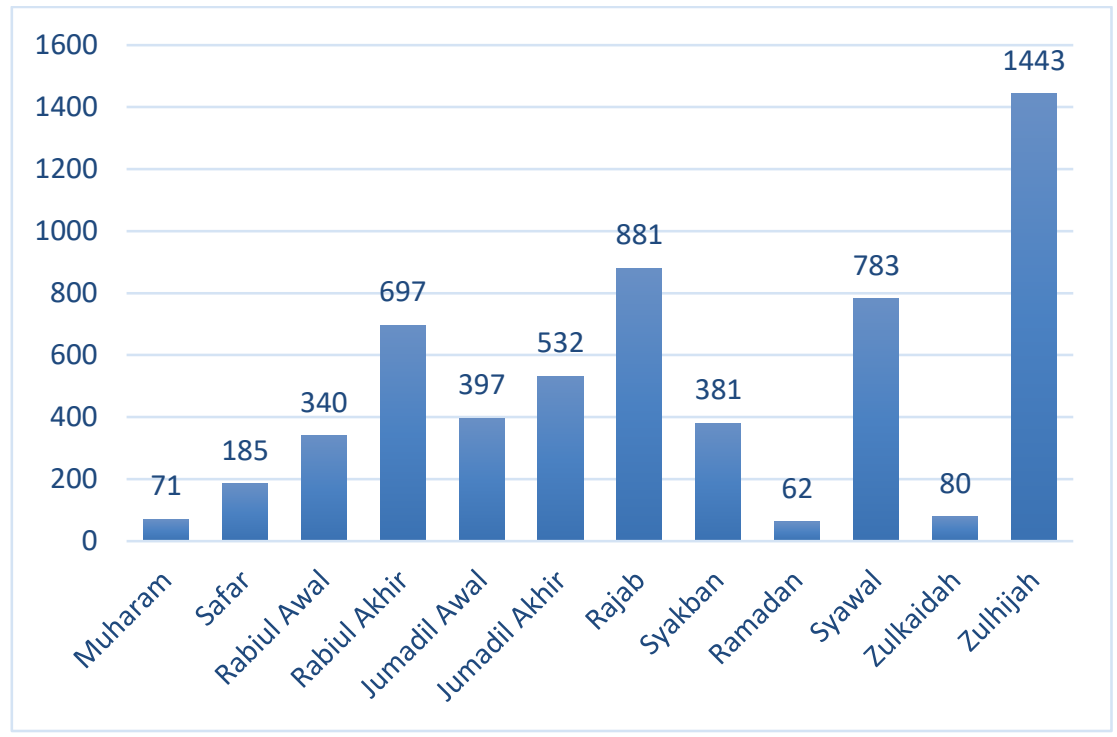

Jika dibandingkan dengan tren di tahun 1984-1985, jumlah perkawinan di bulan pantangan tidak mengalami kenaikan yang signifikan sebagaimana dalam gambar di bawah ini: 
Gambar 2: Jumlah Perkawinan di Kecamatan Sedati Tahun 19841985

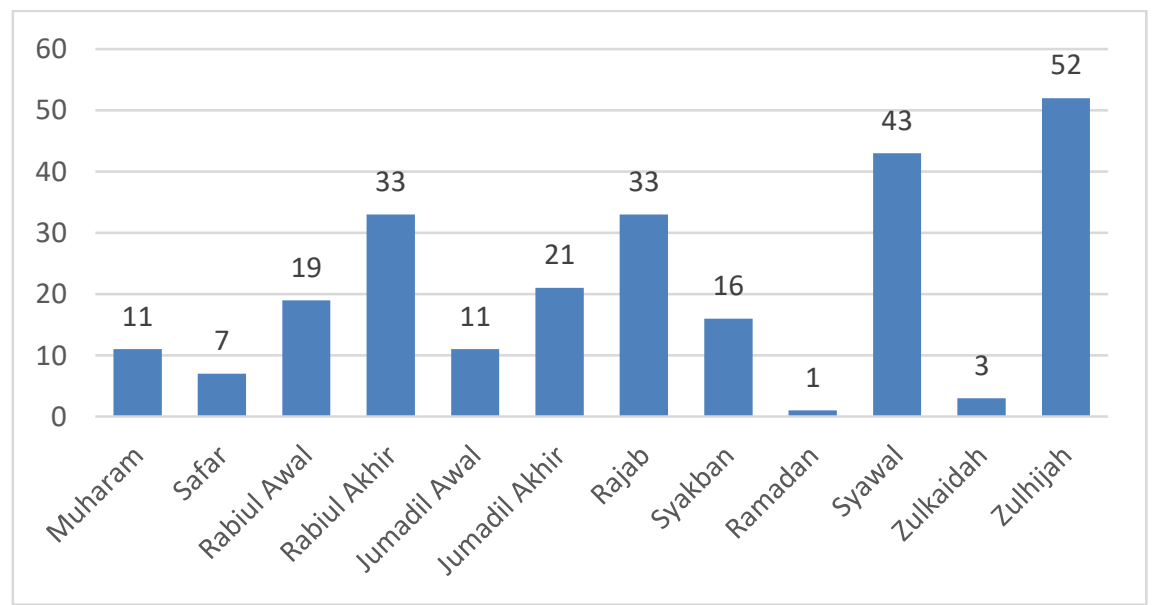

Di kecamatan Waru, terdapat 13.340 perkawinan dalam kurun waktu 10 tahun terakhir. Rata-rata terdapat 1.334 perkawinan tiap tahunnya. Sebaran bulan hijriah perkawinan tersebut sebagaimana dalam gambar di bawah ini:

Gambar 3: Jumlah Perkawinan di Kecamatan Waru 2007-2017

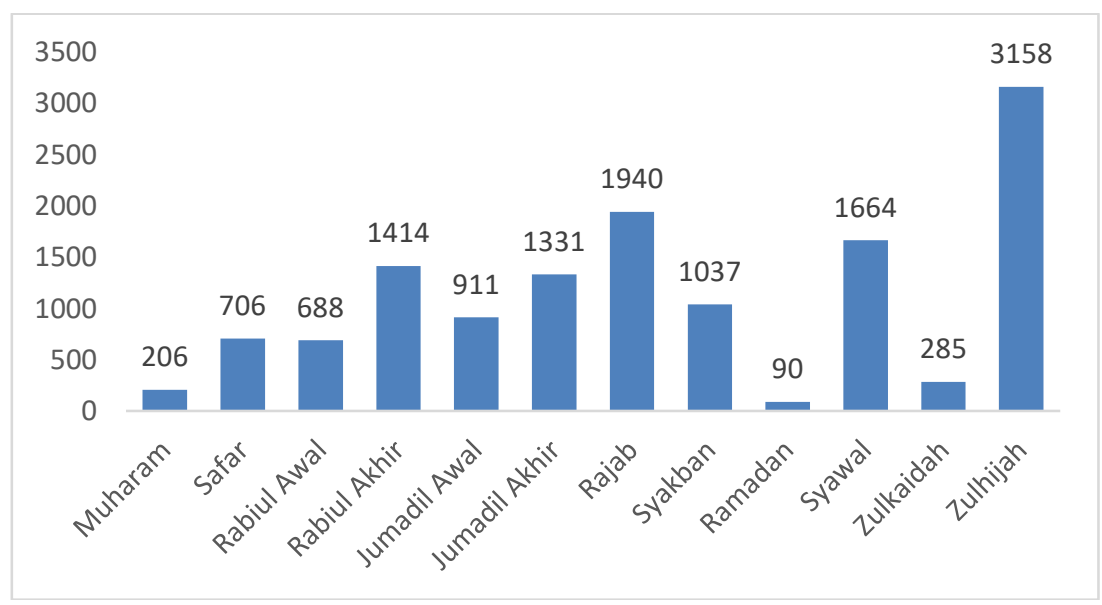


Jika dibandingkan dengan tren di tahun 1984-1985, jumlah perkawinan di bulan pantangan tidak mengalami kenaikan yang signifikan sebagaimana dalam gambar di bawah ini:

Gambar 4: Jumlah Perkawinan

di Kecamatan Waru tahun 1984-1985

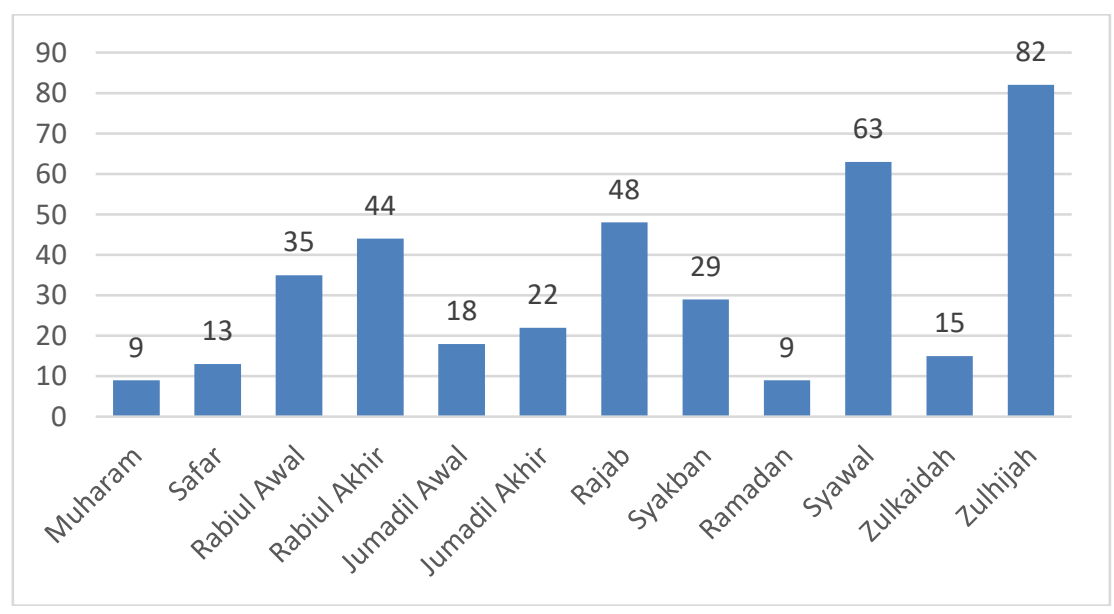

Di kecamatan Buduran, terdapat 5.811 perkawinan dalam kurun waktu 10 tahun terakhir. Rata-rata terdapat 581,1 perkawinan tiap tahunnya. Sebaran bulan hijriah perkawinan tersebut sebagaimana dalam gambar di bawah ini:

Gambar 5: Jumlah Perkawinan di Kecamatan Buduran 2007-2017 
Kemal Riza dkk.: Tren Pernikahan di Bulan Pantangan...

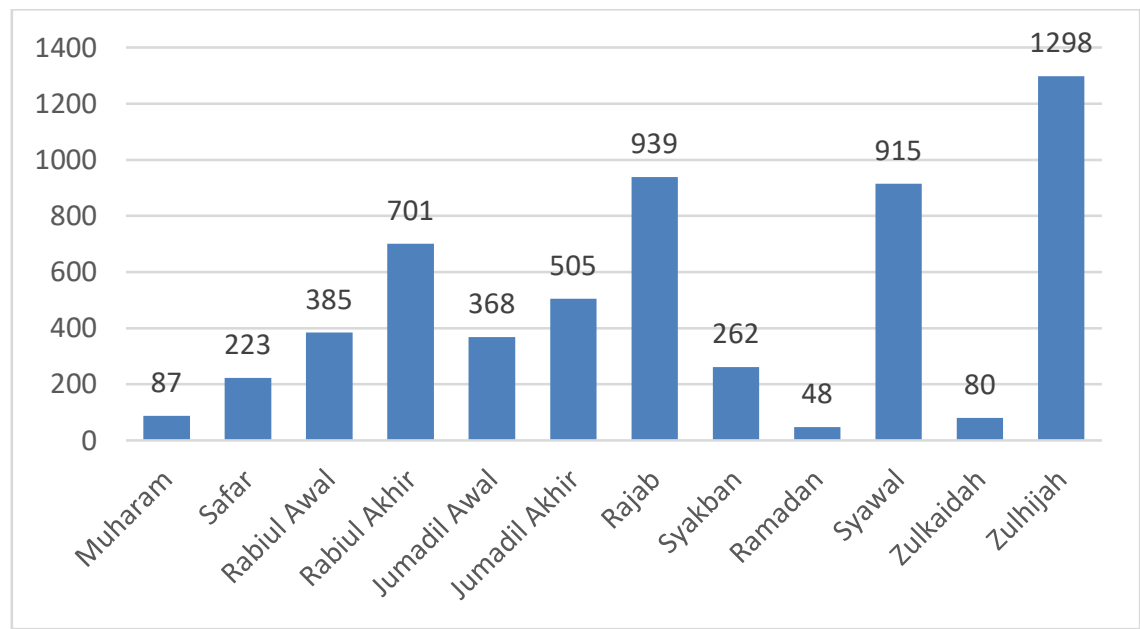

Jika dibandingkan dengan tren di tahun 1984-1985, jumlah perkawinan di bulan pantangan tidak mengalami kenaikan yang signifikan sebagaimana dalam gambar di bawah ini:

Gambar 6: Jumlah Perkawinan di Kecamatan Buduran tahun 1984-1985

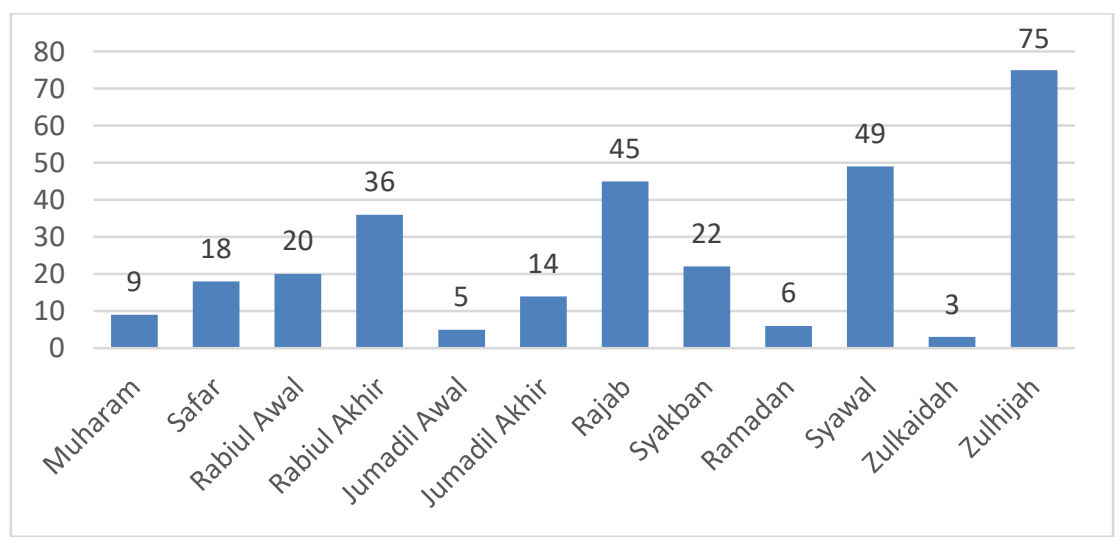

Jika data di tiga kecamatan tersebut digabungkan, maka persentase terjadinya perkawinan berdasarkan bulan Hijriyah adalah sebagai berikut:

Gambar 7: Jumlah Persentase Perkawinan di Tiga Kecamatan 2008-2017 


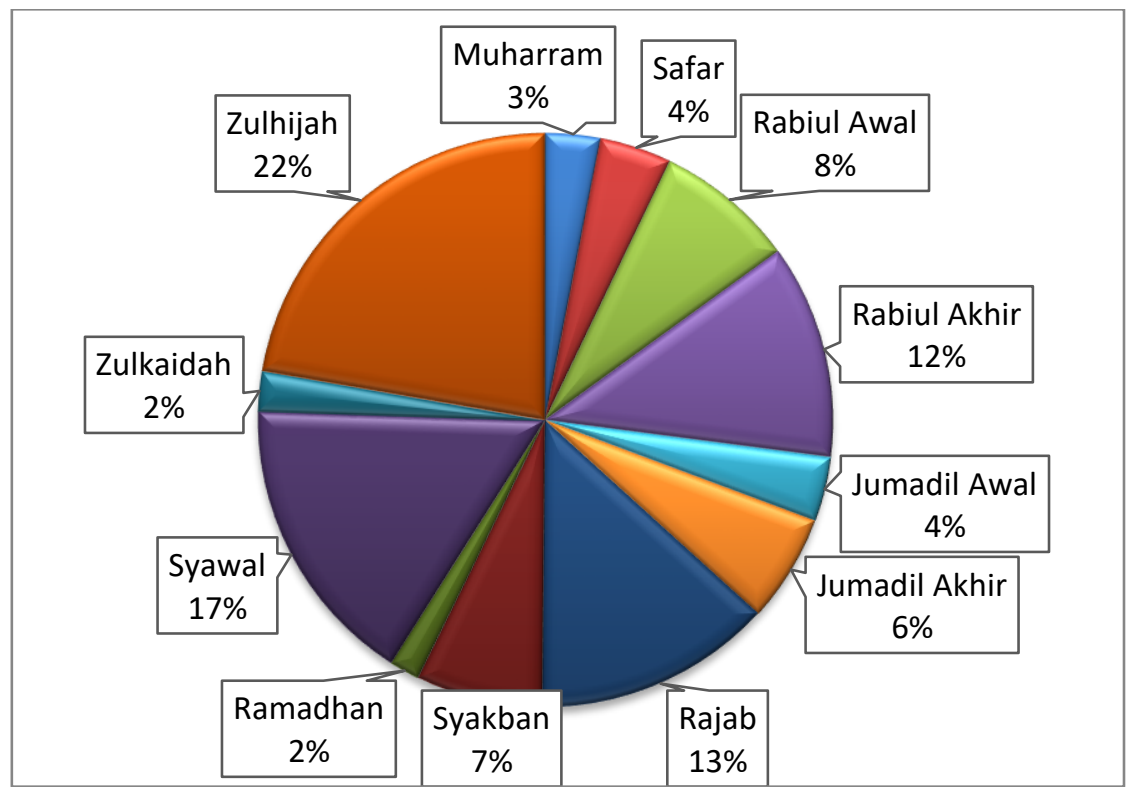

Terlihat pada gambar di atas, bahwa empat bulan yang menurut mitologi orang Jawa dihindari, yakni Suro (Muharam), Mulud (Rabiul Awal), Poso (Ramadan), dan Selo (Zulkaidah), ternyata tidaklah berlaku mutlak. Artinya, masih saja ada pasangan yang menikah di bulan-bulan yang dihindari tersebut. Terutama bulan Rabiul Awal yang dalam Kitab Primbon tidak boleh dilanggar, nyatanya tidak demikian di lapangan. Persentase 8\% terbilang cukup banyak. Ditambah lagi berdasarkan keterangan dari hasil wawancara menyebutkan, bahwa pada bulan Mulud justru banyak pasangan yang menikah.

Jika dibandingkan dengan dekade tahun 1980an, kondisi ini memang mengalami peningkatan walaupun tidak signifikan sebagaimana dalam gambar di bawah ini:

Gambar 8: Jumlah Perkawinan di Tiga Kecamatan Tahun 1984-1985 (1405 H) 


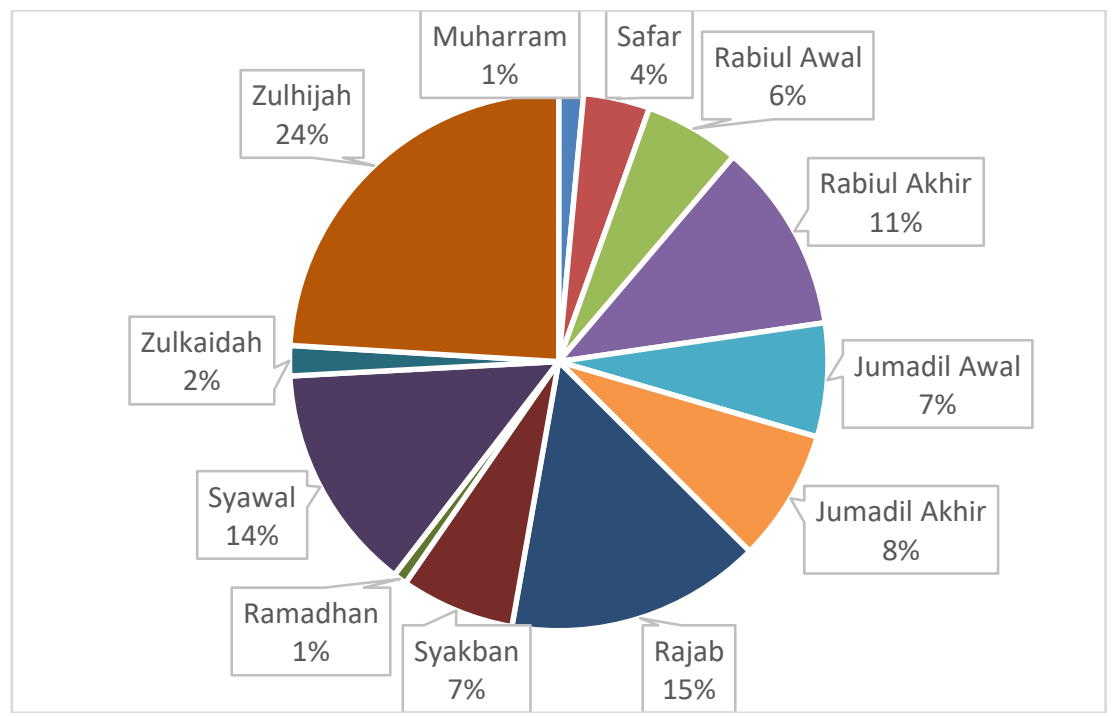

Data di tiga KUA pada tahun 1984-1985 atau $1405 \mathrm{H}$ juga tidak banyak menunjukkan perbedaan yang kontras dibandingkan dengan data yang diambil di 10 tahun terakhir ini. Akan tetapi, perubahan tren terlihat hanya sedikit saja. Di tahun 1984-1985, masyarakat yang menikah di bulan Muharram dan Ramadan jumlahnya hanya $1 \%$ saja, sedangkan data perkawinan 10 tahun terakhir menunjukkan adanya peningkatan, yakni di bulan Muharram menjadi 3\% dan di bulan Ramadan menjadi 2\%.

Bulan Mulud/Rabiul Awal juga mengalami persentase perubahan yang sebelumnya di tahun 1984-1985 sebesar 6\% meningkat menjadi $8 \%$ dalam kurun waktu 10 tahun terakhir. Untuk bulan Besar/Zulkaidah tidak terjadi perubahan sama sekali.

Artinya bahwa, masyarakat Sidoarjo saat ini mulai tergerak untuk tidak terpaku kepada aturan pemilihan bulan. Dahulu, jumlah pasangan yang menikah di empat bulan yang dihindari hanya sedikit. Saat ini, terdapat perubahan tendensi walau persentasenya tidak terlalu signifikan.

\section{Penutup}

Telah terjadi tren perubahan perilaku masyarakat Sidoarjo, yang pada kurun waktu 1984-1985 persentase pasangan yang melakukan perkawinan di bulan yang dihindari sedikit, terlihat ada 
penambahan persentase menurut data yang di ambil pada kurun waktu 10 tahun terakhir.

Masyarakat Sidoarjo secara umum tidak meyakini adanya bulan baik atau bulan buruk untuk menikah, semua bulan adalah bulan baik, sebab al-Qur'an tidak pernah mengajarkan adanya bulan baik maupun bulan buruk. Berbeda dengan teori yang termaktub di dalam Kitab Primbon yang mengatur detail, tak hanya soal bulan menikah, tetapi juga hari bahkan kecocokan pasangan yang akan menikah juga diatur melalui teknis perhitungan tertentu.

Alasan yang menyebabkan pasangan menikah di empat bulan yang dihindari adalah (1) sudah tidak terlalu terpengaruh dengan perhitungan pasangan, bulan, maupun hari dalam primbon Jawa, (2) tidak ada yang namanya bulan baik atau buruk, semua bulan pasti baik, dan (3) karena ada faktor khusus seperti salah satu pasangan hendak bekerja di luar kota/pulau atau karena terjadi hamil di luar nikah.

\section{Daftar Pustaka}

Abi al-Hasan Muslim ibn al-Hajjaj ibn Muslim al-Qushayri alNaysaburi, Sabih Muslim, (Riyad: Dar al-Hadarah li alNashar wa al-Tawzi', 2015), 437.

Harya Cakraningrat, Kitab Primbon: Betaljemur Adammakna, (Yogyakarta: Soemodidjojo Mahadewa, 2017), 7.

Ibn Kathir, al-Bidayah wa al-Nihayah, Juz 3, (Kuwait: al-Muassasah Zad, 2001), 253.

Islampos: Media Islam Generasi Baru, Pada Bulan-bulan Inilah Rasulullah Menikah, https://www/islampos.com/padabulan-bulan-inilah-rasulullah-menikah-126140/

Yahya ibn Sharaf al-Nawawi, Sharb Sabih Muslim, Juz 9, (Cairo: Dar al-Hadith, 2002), 209.

Abd. Muntholib, Wawancara, 29 September 2017.

Abdul Ghofur, Wawancara, 06 Oktober 2017.

Ahmad Fathoni, Wawancara, 27 September 2017.

Amin Tohari, Wawancara, 06 Oktober 2017.

Arief Edward, Wawancara, 22 September 2017. 
Chudlori, Wawancara, 09 Oktober 2017.

Fatkur Rochman, Wawancara, 09 Oktober 2017.

Ischaq Fathani, Wawancara, 27 September 2017.

M. Shocibullah, Wawancara, 10 Oktober 2017.

Misbahul Munir, Wawancara, 03 Oktober 2017.

Muhammad Khusaeri, Wawancara, 29 September 2017. 